\title{
Two Houses: Legislative Studies and the Atlantic Divide
}

\author{
Shane Martin, Dublin City University
}

\begin{abstract}
egislative scholars have a history of L stepping back occasionally to examine the development and state of the subdiscipline (Budge 1973; Gamm and Huber 2002; Loewenberg, Patterson, and Jewell 1985; Mezey 1993; Morris-Jones 1983; Pasquino 1973; Patterson 1989).

Many of these existing reviews, although valuable, are predominantly of a qualitative and subjective nature and are, in most cases, now dated. This paper provides a bibliometrical analysis of the state of legislative studies in the United States and Europe by exploring the content of eight political science journals. ${ }^{1} \mathrm{I}$ looked at six general political science journals, three originating in the United States and three in Europe, as well as the content of two legislative studies journals - the American-based Legislative Studies Quarterly and the British-based Journal of Legislative Studies.
\end{abstract}

It is generally agreed that political science lacks a common underlying theoretical outlook and agenda for research (Garand 2005). Scholarship emerging from North American and Europe is generally seen as having two very distinct "styles"- the former being focused on theoretical rigor and empirical data collection and analysis with the latter concentrating on more descriptive accounts of political behavior. ${ }^{2}$ For the majority of the North American community, political science is an empirical social science, while in Europe, political science, or the subject commonly referred to as politics, is more closely tied to its historical roots in philosophy or constitutional and administrative law. I explore here the degree to which such a divide exists today in legislative studies. Given the significant role that some consider legislative studies to play in shaping the wider discipline (Shepsle 2002), this analysis will be of interest to political scientists re-

Shane Martin lectures in comparative politics at Dublin City University. $\mathrm{He}$ is cofounder of the ECPR Standing Group on Parliaments. In the United States, he has previously taught at the Pennsylvania State University and the University of California, San Diego. His research focuses on role orientation and the electoral connection. gardless of their particular research and teaching focus.

The novelty of this article is twofold: I provide a detailed bibliometric examination of the state of legislative scholarship in the United States and Europe and investigate and comment upon the similarities and differences between legislative scholarship in the two regions. I explore questions as to the relative amount of output, the country and institution being analyzed, the subject matter, and the methodology employed. In addition, I use data on the level of interregional collaboration, as measured through co-authorship patterns, to provide further insight into the recent evolution of the discipline and the strength of the divide.

\section{Data and Methods}

Bibliometrics relies on the quantitative analysis of published works. Publications are important because they spread scientific findings. Legislative scholars, like political scientists in general, rely on a whole range of publication channels including conference papers, monographs, books, and journal articles. This paper focuses on one single unit of research output, namely journal articles. Journals are the primary forum to convey cutting edge research within the profession. I excluded books, despite the obvious fact that they contain many important insights and are important mechanisms for communicating research. Ideally, a bibliometric analysis of a discipline requires one to look at all forms of publication. Unfortunately such a task is beyond the scope of this paper.

I selected six general political science journals for content analysis. The three U.S. general journals are the American Political Science Review (APSR), one of the three journals of the American Political Science Association; the American Journal of Political Science (AJPS), the official journal of the Midwest Political Science Association; and the Journal of Politics (JOP), published in association with the Southern Political Science Association. I selected these journals because they achieved the highest scores in the study by Garand and Giles (2003) of impact rankings of political science journals. Thus the APSR, AJPS, and JOP can be considered the "top three" general journals in the United States. Selecting the "leading" European journals proves more elusive given the absence of any pan-European journal rankings. An appropriate proxy is the rankings of European journals by British political scientists conducted by the British Political Studies Association (Crewe and Norris 1991). Here, Political Studies (PS), the official journal of the Political Studies Association, scores strongest on impact followed by the British Journal of Political Science (BJPS), which is published independent of any professional association by Cambridge University Press. The third European journal for this study, the European Journal of Political Research $(E J P R)$, is included due to its status as the official journal of the European Consortium for Political Research (ECPR), which makes it the most widely recognized general pan-European journal in the discipline.

I include in this analysis two journals of particular interest and importance to legislative scholars: the U.S.-based Legislative Studies Quarterly ( $L S Q)$ and the British-based Journal of Legislative Studies (JLS). LSQ had always achieved high rankings and is considered one of the highest ranking specialty journalsperhaps itself an indication of the status of legislative studies within the wider discipline. ${ }^{3}$ The slightly more youthful Journal of Legislative Studies was first published in 1995 and quickly established itself as a favored source for output among legislative scholars, including many of the leading scholars in the discipline.

I analyzed articles from each of the eight journals journal over the period 1995-2006. I defined articles as substantive papers and I only included research articles or "other articles" that I consider to have substantive original research. Typically I excluded editor's notes, debates, comments, communications, replies and responses, and rejoinders and counter-rejoinders. In total, I analyzed the titles and abstracts of 2,687 articles to see if they were connected to legislative studies and were research substantive. Of 
Table 1

Primary Methodology of Legislative Studies Articles as a Percent of all Legislative Studies Articles

\begin{tabular}{|c|c|c|c|c|c|}
\hline Methodology & $\begin{array}{c}\text { APSR, } \\
\text { AJPS, JOP }\end{array}$ & $\begin{array}{c}P S, \\
B J P S, E J P R\end{array}$ & $L S Q$ & $J L S$ & All \\
\hline Data Presentation, no theory & 1.3 & 18.7 & 2.2 & 0.0 & 2.3 \\
\hline Non-formal, non-quantitative theoretical & 2.5 & 15.0 & 11.1 & 77.2 & 33.2 \\
\hline Informal theoretical model, quantitative empirics & 80.6 & 54.5 & 76.7 & 19.8 & 56.2 \\
\hline Formal model with quantitative empirics & 5.3 & 10.6 & 6.7 & 2.2 & 4.7 \\
\hline \multirow[t]{2}{*}{ Formal theoretical model, no-empirics } & 10.2 & 1.2 & 3.3 & 0.9 & 3.6 \\
\hline & 99.9 & 100.0 & 100.0 & 100.0 & 100.0 \\
\hline \multicolumn{6}{|l|}{ Note: Total may not add up to 100 due to rounding. } \\
\hline $\begin{array}{l}\text { APSR }=\text { American Political Science Review } \\
\text { AJPS }=\text { American Journal of Political Science } \\
\text { JOP }=\text { Journal of Politics } \\
P S \quad=\text { Political Studies }\end{array}$ & \multicolumn{5}{|c|}{$\begin{array}{l}\text { BJPS }=\text { British Journal of Political Science } \\
E J P R=\text { European Journal of Political Research } \\
L S Q=\text { Legislative Studies Quarterly } \\
J L S=\text { The Journal of Legislative Studies }\end{array}$} \\
\hline
\end{tabular}

these articles, I found 887 that constituted legislative research. The Appendix provides a detailed description of how I demarcated legislative and non-legislative research. I further reviewed each of these articles and the content recorded for analysis. I discuss the questions and findings from the content analysis below.

\section{Findings}

\section{Methodology}

A key feature of a unified discipline is a common methodological approach based on an underlying paradigm. However, there appears to be no such underlying paradigm within legislative studies. Table 1 shows the differences in methodological orientation between legislative studies papers in the select U.S. and European journals. I coded each article based on five different characterizations of methodology ranging from purely formal modeling with no empirics to purely empirical work (data presentation). I further differentiated between qualitative (case study) and quantitative (large- $\mathrm{N}$ statistical) work. In general, the results are in keeping with the findings of Norris (1997), who analyzed a sample of articles in three political science journals. She found $P S$ tends to be heavily weighted towards philosophical and descriptive/institutional methods. The APSR tends towards more empirical methods and rational choice/deductive approaches. We can see that in the case of legislative studies this difference in methodological style is exacerbated. Legislative articles published in the three U.S. journals are far more likely to contain deductive theory, make use of mathematical reasoning, or be large-N quantitative. While a significant proportion of the European journal articles are quantitative, the thick descriptive approach is still frequently employed with purely theoretical works relatively rare.

Based on the data in Table 1, it seems reasonable to conclude that the difference in theoretical orientation between U.S. and European legislative scholarship is a prime example of what King, Keohane, and Verba $(1994,4)$ described as "the bifurcation of the social sciences into a quantitative-systematic-generalizing branch and a qualitative-humanisticdiscursive branch." European scholars tend to rely on inductive and descriptive methods of inquiry while American scholars focus more on quantitative analysis of a priori theoretical reasoning, or in some cases on purely deductive reasoning without empirical tests. It should be noted however that some of the general European journals and the $J L S$ do publish work comprising of formals models and/or formal models with some empirical test.

If scholars seek to export or import the dominant paradigms and methodology of American legislative scholarship, they must deal with issues of environmental and institutional sensitivity, or what Mezey (1991) refers to as "taking the legislature out of context." All national assemblies share something in common, but there are many important differences. Indeed, American exceptionalism may well be responsible for the lack of cross-regional integration in legislative studies. Applying a congressional model unaltered to a parliament in another country may be problematic for a number of reasons. Even if we assume that legislators are goal oriented (an almost unquestioned assumption in Ameri- can scholarship), can we assume that the re-election goals of members of Congress are the same as members of a legislature operating under parliamentarism who may have their eyes on promotion rather than re-election? For example, in a groundbreaking paper, Strøm (1997) argues that legislators in some countries must focus on reselection, re-election, and promotion to higher political office.

We must not neglect the occasionally lively debate within the U.S. on the status of theory and in particular the antirational choice movement, symbolized by the publication some years ago of $\mathrm{Pa}$ thologies of Rational Choice Theory (Green and Shapiro 1994). More recently, the emergence and influence of the Perestroika movement in the U.S. has sought to make American political science, which legislative studies is undoubtedly a significant part of, more methodologically plural (Monroe 2005). And even within the family of positive political economy we need to be aware of internal divisions, particularly in the presence of divergent theories with similar empirical predictions (Shepsle and Weingast 1995).

Even if European legislative scholarship is weak in theoretical orientation it is even weaker when it comes to the existence of empirical data on European legislatures. Many Congressional scholars who interact with European colleagues are rightly amused, not just at the atheoretical state of comparative research but at the absence of hard data of even the most rudimentary type for many parliaments. While scholars have built up collections of data on some parliaments, none come close to the quality and amount of data on the U.S. Congress. Moreover, the amount of 


\begin{tabular}{lcc}
$\begin{array}{l}\text { Table } 2 \\
\text { Legislative Studies Articles in Eight Political Science }\end{array}$ & Journals \\
\hline & Number & $\begin{array}{c}\text { Percent of } \\
\text { Total Articles }\end{array}$ \\
Journal & 56 & 11.5 \\
\hline American Political Science Review (APSR) & 95 & 21.5 \\
American Journal of Political Science (AJPS) & 82 & 20.2 \\
Journal of Politics (JOP) & 233 & 17.8 \\
General American journals combined & 14 & 4.5 \\
Political Studies (PS) & 27 & 14.8 \\
British Journal of Political Science (BJPS) & 19 & 7.3 \\
European Journal of Political Research (EJPR) & 60 & 8.9 \\
General European journals combined & 270 & 100.0 \\
Legislative Studies Quarterly (LSQ) & 324 & 98.8 \\
Journal of Legislative Studies (JLS) & 887 & 34.8 \\
All eight journals & &
\end{tabular}

cross-institutional data is very limited. One can look to examples such as the study of western European legislatures headed by Herbert Döring (1995), but even here the data provide a snapshot at a particular period of time rather than a temporal perspective.

Finally, it should be noted that just as a discipline or sub-discipline evolves, so too will the study of an individual legislature. A graduate student who decides to study a legislature that has remained relatively unexplored (and as we will discuss below, many such legislatures exist) may find it difficult to do anything but the most elementary of storytelling, particularly at the initial research stages. The study of any individual legislature begins with a large amount of observation and reporting of elementary facts. This may explain in part why so many articles in European journals, which are more likely to be focused on understudied legislatures, are of the descriptive, non-quantitative type. It may also help explain the unwillingness of U.S.-based scholars to study under-researched European legislatures, as the starting point for such research is likely to include expensive and time consuming information and data collecting fieldwork. Data on American politics is likely to be more readily available and even machine readable.

\section{Publication Rates}

Table 2 reports the rate of legislative studies articles to total articles in the eight journals over the period 19952006. Overall, legislative research accounts for just less than $35 \%$ of all research, although this number is misleading given the inclusion of two specialist journals. In the six general political science journals, just less than $15 \%$ of all articles relate to legislatures. Although this percentage may at first appear low, it is perhaps surprisingly large when we remember how diverse the research interests of the political science community have become. ${ }^{4}$

When I examined the distribution of legislative studies article by journal, the trends were striking. The three U.S. journals published 233 legislative studies articles, which equates to just under $80 \%$ of legislative articles in all six general journals. By itself, the AJPS accounts for over a third of all legislative studies articles in the six journals. In contrast, the number of legislative studies articles in each of the three general European journals is in double rather than triple digits.

I should note that for the period under review the total number of articles is less in the three European journals than in the U.S. general journals (over the period the U.S. journals accounted for $64 \%$ of articles in the six general journals). To control for different overall output, I compared the ratio of legislative studies articles to non-legislative studies articles in each journal. When I took the rate of legislative studies articles to total output the figures did not change dramatically: $21 \%$ of AJPS articles, $20 \%$ of JOP articles, and $11 \%$ of APSR articles are legislative related. While $15 \%$ of the BJPS can be categorized as legislative studies, the EJPR includes less than $8 \%$ legislative studies. PS makes the lowest contribution to legislative output in any of the journals reviewed, with less that $5 \%$ of its content being legislative scholarship. Overall, the picture is relatively clear: of the six general journals reviewed, the three U.S. publications account for some $80 \%$ of legislative studies articles. Even when the rate of article production is taken into account, one is twice as likely to see a legislative studies article in an American journal than in a European journal-just under $9 \%$ of all articles in the three general European journals are legislative studies, compared with nearly $18 \%$ in the three leading American journals. The only outlier is the BJPS, which published significantly more legislative scholarship than the other two European journals.

Including articles from the two specialist journals slightly decreases the overall difference between Europe and the United States legislative studies output as the $J L S$ published slightly more articles than $L S Q$ during the period under review. Nevertheless, a huge gap still exists between the amount and rate of legislative studies being published in the two regions.

\section{Country/Institution Focus}

To explore further the possibility of regional imbalance, I examined the country focus of research. The results are in Table 3 for research focused on one country and in Table 4 for multi-country legislative research.

The figures are striking in that they provide further evidence of American dominance in legislative studies. Some 426 articles have been published on legislatures in the United States (either the United States Congress, state, or local legislatures). Indeed legislative politics in America is the focus of just under half of all published research in the eight journals. The next most studied legislature is that of the United Kingdom, with the vast majority on the House of Commons. The European parliament scores next highest, which, despite its short lifetime (it was first popularly elected in 1979), has caught the attention of American and European scholars alike. Thereafter, the parliaments of other countries individually account for less than $2 \%$ of legislative research. The focus on American legislatures is even more unequivocal in American journals with over two-thirds of legislative studies articles in the top three journals focusing on United States legislatures and over $80 \%$ of articles in $L S Q$ focusing on the United States. Overall, Table 3 points to an extraordinary, if not surprising, imbalance in terms of which countries are the subject of study by legislative scholars.

One of the most interesting points to emerge from Table 4, which reports the country focus of multi-country studies, is the relatively low rate of cross-national comparative research in legislative studies. Just $12 \%$ of legislative studies 
Table 3

\section{Focus of Single Country Studies as a Percent of Legislative Studies Articles}

\begin{tabular}{|c|c|c|c|c|c|}
\hline Country/Institution & $\begin{array}{c}\text { APSR, } \\
\text { AJPS, JOP }\end{array}$ & $\begin{array}{c}P S, \\
B J P S, E J P R\end{array}$ & $L S Q$ & $J L S$ & All \\
\hline United States & 76.0 & 11.7 & 81.5 & 6.8 & 48.0 \\
\hline United Kingdom & 0.0 & 25.0 & 0.7 & 24.4 & 10.8 \\
\hline European Parliament & 0.4 & 10.0 & 1.1 & 9.3 & 4.5 \\
\hline Italy & 1.3 & 8.3 & 0.4 & 2.8 & 2.0 \\
\hline Germany & 1.3 & 3.3 & 0.4 & 3.1 & 1.8 \\
\hline Brazil & 1.3 & 0.0 & 3.0 & 0.6 & 1.5 \\
\hline Russia & 0.9 & 0.0 & 1.5 & 2.2 & 1.5 \\
\hline Canada & 0.0 & 0.0 & 0.0 & 3.4 & 1.2 \\
\hline Japan & 1.3 & 1.7 & 0.4 & 0.9 & 0.9 \\
\hline Australia & 0.9 & 1.7 & 0.4 & 0.9 & 0.8 \\
\hline Denmark & 0.0 & 0.0 & 0.0 & 2.2 & 0.8 \\
\hline Israel & 0.0 & 0.0 & 0.7 & 1.5 & 0.8 \\
\hline Norway & 0.4 & 1.7 & 0.0 & 1.5 & 0.8 \\
\hline France & 0.0 & 3.3 & 0.0 & 1.2 & 0.7 \\
\hline Netherlands & 0.0 & 1.7 & 0.4 & 1.2 & 0.7 \\
\hline Argentina & 0.9 & 0.0 & 0.0 & 0.9 & 0.6 \\
\hline Spain & 0.0 & 0.0 & 0.0 & 1.5 & 0.6 \\
\hline Hungary & 0.0 & 0.0 & 0.4 & 0.9 & 0.5 \\
\hline Ireland & 0.0 & 0.0 & 0.0 & 1.2 & 0.5 \\
\hline New Zealand & 0.0 & 0.0 & 0.0 & 1.2 & 0.5 \\
\hline Portugal & 0.0 & 0.0 & 0.0 & 1.2 & 0.5 \\
\hline Bangladesh & 0.0 & 0.0 & 0.4 & 0.6 & 0.3 \\
\hline China & 0.0 & 0.0 & 0.4 & 0.6 & 0.3 \\
\hline Colombia & 0.9 & 0.0 & 0.4 & 0.0 & 0.3 \\
\hline Czech Republic & 0.0 & 0.0 & 0.7 & 0.3 & 0.3 \\
\hline Finland & 0.0 & 0.0 & 0.0 & 0.9 & 0.3 \\
\hline Iceland & 0.0 & 1.7 & 0.0 & 0.6 & 0.3 \\
\hline Ukraine & 0.0 & 0.0 & 0.4 & 0.6 & 0.3 \\
\hline Belgium & 0.0 & 0.0 & 0.0 & 0.6 & 0.2 \\
\hline India & 0.0 & 0.0 & 0.0 & 0.6 & 0.2 \\
\hline Korea & 0.0 & 0.0 & 0.0 & 0.6 & 0.2 \\
\hline Mexico & 0.0 & 0.0 & 0.4 & 0.3 & 0.2 \\
\hline Poland & 0.0 & 0.0 & 0.0 & 0.6 & 0.2 \\
\hline Sweden & 0.0 & 0.0 & 0.0 & 0.6 & 0.2 \\
\hline Trinidad and Tobago & 0.0 & 0.0 & 0.0 & 0.6 & 0.2 \\
\hline Bulgaria & 0.0 & 0.0 & 0.0 & 0.3 & 0.1 \\
\hline Chile & 0.4 & 0.0 & 0.0 & 0.0 & 0.1 \\
\hline Estonia & 0.0 & 0.0 & 0.0 & 0.3 & 0.1 \\
\hline Greece & 0.0 & 0.0 & 0.0 & 0.3 & 0.1 \\
\hline Honduras & 0.0 & 0.0 & 0.0 & 0.3 & 0.1 \\
\hline Kosovo & 0.0 & 0.0 & 0.0 & 0.3 & 0.1 \\
\hline Mongolia & 0.0 & 0.0 & 0.0 & 0.3 & 0.1 \\
\hline Morocco & 0.0 & 0.0 & 0.0 & 0.3 & 0.1 \\
\hline Nepal & 0.0 & 0.0 & 0.0 & 0.3 & 0.1 \\
\hline Singapore & 0.0 & 0.0 & 0.4 & 0.0 & 0.1 \\
\hline Slovakia & 0.0 & 0.0 & 0.0 & 0.3 & 0.1 \\
\hline South Africa & 0.0 & 0.0 & 0.0 & 0.3 & 0.1 \\
\hline Taiwan & 0.0 & 0.0 & 0.4 & 0.0 & 0.1 \\
\hline Turkey & 0.0 & 0.0 & 0.0 & 0.3 & 0.1 \\
\hline Uruguay & 0.0 & 0.0 & 0.0 & 0.3 & 0.1 \\
\hline Zambia & 0.0 & 0.0 & 0.0 & 0.3 & 0.1 \\
\hline Total & 85.8 & 70.0 & 94.1 & 80.9 & 85.5 \\
\hline
\end{tabular}

Note: Total does not add up to 100 because of the exclusion of multi-country articles (see table 4 below) and non-empirical articles.

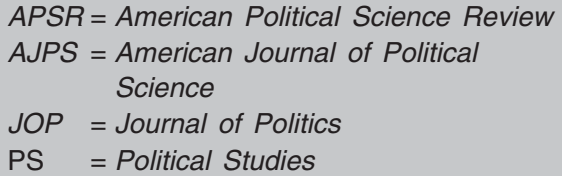

\section{BJPS = British Journal of Political Science $E J P R=$ European Journal of Political Research \\ $L S Q=$ Legislative Studies Quarterly \\ JLS = The Journal of Legislative Studies}

articles are (cross-country) comparative, with $85 \%$ of legislative studies articles focusing on one country. ${ }^{5}$ The most common form of comparative legislative studies involves examining the parliaments of three or more European countries. In the articles I reviewed, the U.S. Congress has only been compared a handful of times to parliaments in other countries, and all of these are Englishspeaking countries with the exception of Germany, Japan, and the multilingual European Parliament.

In Table 5 I report the specific legislatures that scholars are studying in each country. Looking at all eight journals, the U.S. House of Representatives accounts for a quarter of all legislative studies research, nearly equaling all research on lower or unicameral chambers in all other countries combined. A noteworthy finding is that research on the House is significantly greater than on the United States Senate by a margin of four to one. This surely has huge significance for the study of American politics, and it is a little difficult to explain given the importance and significance of the Senate in American politics.

I also observed a significant difference in which journals publish articles on which institutions. While a plurality of articles published in U.S. journals are on the U.S. House of Representatives, a different picture emerges in the four European journals where for both the three general journals and $J L S$, almost half of articles are published on the lower or unicameral chamber of a national legislature of a country other than the United States. The focus on lower chambers outside America is less surprising, given the presence of unicameral systems and the general dominance of the lower chamber over the upper chamber in many political systems.

In summary, I see relatively clear patterns of research, with little crossnational research and a relative abundance of research on American legislative institutions in general and the House of Representatives in particular.

\section{Subject Matter}

Parliaments are complex institutions made even more complex by their interaction with other parts of the political system. What exactly then is it about legislatures that scholars study? To help answer this question, I identified the primary subject matter of each article and the categorization and findings are in Table 6.

The interaction between the executive and legislature is a significant subject in published research in legislative studies. 
Table 4

Geographical Focus of Multi Country Studies as a Percent of all Legislative Studies Articles

\begin{tabular}{|c|c|c|c|c|c|}
\hline Country/Institution & $\begin{array}{c}\text { APSR, } \\
\text { AJPS, JOP }\end{array}$ & $\begin{array}{c}P S, \\
B J P S, E J P R\end{array}$ & $L S Q$ & $J L S$ & All \\
\hline More than two European countries & 11.0 & 14.0 & 9.0 & 13.0 & 5.3 \\
\hline Two European countries & 3.0 & & 2.0 & 2.0 & 0.8 \\
\hline More than two South American countries & 1.0 & & 1.0 & 3.0 & 0.6 \\
\hline United States and the United Kingdom & & 1.0 & 1.0 & 1.0 & 0.3 \\
\hline United States and Canada & 1.0 & & & & 0.1 \\
\hline United States and New Zealand & 1.0 & & & & 0.1 \\
\hline United States and European Parliament & & & 1.0 & & 0.1 \\
\hline United States and Germany & & & & 1.0 & 0.1 \\
\hline Canada and United Kingdom & & & & 1.0 & 0.1 \\
\hline Two South American countries & 1.0 & & & & 0.1 \\
\hline $\begin{array}{l}\text { APSR }=\text { American Political Science Review } \\
\text { AJPS }=\text { American Journal of Political Science } \\
\text { JOP }=\text { Journal of Politics } \\
\text { PS } \quad=\text { Political Studies }\end{array}$ & \multicolumn{5}{|c|}{$\begin{array}{l}\text { BJPS }=\text { British Journal of Political Science } \\
\text { EJPR }=\text { European Journal of Political Research } \\
\text { LSQ }=\text { Legislative Studies Quarterly } \\
J L S=\text { The Journal of Legislative Studies }\end{array}$} \\
\hline
\end{tabular}

Table 5

Specific Institutional Focus as a Percent of all Legislative Studies Articles

\begin{tabular}{|c|c|c|c|c|c|}
\hline Institution & $\begin{array}{c}\text { APSR, } \\
\text { AJPS, JOP }\end{array}$ & $\begin{array}{c}P S, \\
\text { BJPS, EJPR }\end{array}$ & $L S Q$ & $J L S$ & All \\
\hline U.S., local level & 1.9 & 0.0 & 0.4 & 0.0 & 0.7 \\
\hline U.S., House of Representatives & 39.7 & 7.3 & 39.3 & 4.3 & 24.5 \\
\hline U.S., Senate & 9.2 & 0.0 & 9.6 & 0.3 & 5.6 \\
\hline U.S., both chambers & 11.7 & 1.2 & 14.8 & 1.2 & 7.9 \\
\hline Non-U.S., second chamber & 0.0 & 9.0 & 0.7 & 4.0 & 2.3 \\
\hline Non-.U.S, both chambers & 3.2 & 17.3 & 0.7 & 16.0 & 8.2 \\
\hline Other & 9.1 & 6.2 & 7.8 & 14.5 & 10.3 \\
\hline Total & 100.0 & 100.0 & 100.0 & 100.0 & 100.0 \\
\hline $\begin{array}{l}\text { APSR }=\text { American Political Science Review } \\
\text { AJPS }=\text { American Journal of Political Science } \\
\text { JOP }=\text { Journal of Politics } \\
P S \quad=\text { Political Studies }\end{array}$ & $\begin{array}{l}B J P S= \\
E J P R= \\
L S Q= \\
J L S=\end{array}$ & $\begin{array}{l}\text { Journal of Polit } \\
\text { an Journal of } P \\
\text { ive Studies Qu } \\
\text { urnal of Legisla }\end{array}$ & Researc & & \\
\hline
\end{tabular}

This is not surprising given the importance of the separation of branches in the most studied country (the United States) and the key role of the executive in the political life of parliamentary democracies. Legislative-executive relations account for just over $11 \%$ of legislative studies articles in the general U.S. journals and close to $17 \%$ of legislative studies articles in the three general European journals. In European parliamentary sys- tems, the executive comes from and remains accountable to, but also frequently dominates, the legislature, which may prompt European scholars to be more focused on executive-legislative relations and less interested in topics such as the internal organization of parliaments.

The single largest legislative studies topic dealt with by American journals is the electoral responsiveness of members. This accounts for close to $15 \%$ of arti- cles in the three U.S. journals. Research on responsiveness is dramatically less in the European journals, accounting for less than $2 \%$ of legislative research. Other subjects that receive a significant amount of attention in the general U.S. journals include internal procedures, committees, minority and gender representation, and research seeking to explain the voting behavior of members. European journals are most focused on the 
Table 6

Subject Matter of Legislative Studies Articles as a Percent of all Legislative Studies Articles

\begin{tabular}{|c|c|c|c|c|c|}
\hline & $\begin{array}{c}\text { APSR, } \\
\text { AJPS, JOP }\end{array}$ & $\begin{array}{c}P S, \\
\text { BJPS, EJPR }\end{array}$ & LSQ & JLS & All \\
\hline Legislative-executive relations & 11.2 & 16.7 & 9.3 & 21.6 & 14.8 \\
\hline Organizational attributes/procedures & 9.9 & 5.0 & 10.0 & 14.5 & 11.3 \\
\hline Committees & 10.3 & 8.3 & 4.1 & 7.1 & 7.1 \\
\hline Bicameralism & 1.7 & 6.7 & 1.5 & 7.7 & 4.2 \\
\hline Representation/roles/role orientation & 6.0 & 3.3 & 5.9 & 7.1 & 6.2 \\
\hline Member voting behavior & 9.0 & 13.3 & 13.7 & 7.1 & 10.0 \\
\hline Legislative parties/leadership & 1.3 & 3.3 & 5.9 & 3.7 & 3.7 \\
\hline Electoral responsiveness & 14.6 & 1.7 & 12.6 & 1.2 & 8.2 \\
\hline Candidates/incumbency & 3.4 & 0.0 & 14.4 & 3.1 & 6.4 \\
\hline Interest groups/lobbying & 2.1 & 0.0 & 4.4 & 1.2 & 2.4 \\
\hline Member background/careers & 4.7 & 6.7 & 6.7 & 3.1 & 4.8 \\
\hline Government formation/coalition theory & 6.4 & 21.7 & 1.1 & 0.3 & 3.6 \\
\hline Legislation/legislative output & 7.3 & 0.0 & 4.4 & 4.6 & 5.0 \\
\hline National parliaments and the European Union & 0.0 & 0.0 & 0.0 & 12.0 & 4.4 \\
\hline Minority and gender representation & 9.9 & 10.0 & 5.6 & 1.5 & 5.5 \\
\hline Methodology & 0.0 & 0.0 & 0.4 & 1.9 & 0.8 \\
\hline Other & 2.1 & 3.3 & 0.0 & 2.2 & 1.6 \\
\hline Total & 99.9 & 100 & 100 & 99.9 & 100 \\
\hline
\end{tabular}

Note: Total may not add up to 100 due to rounding.

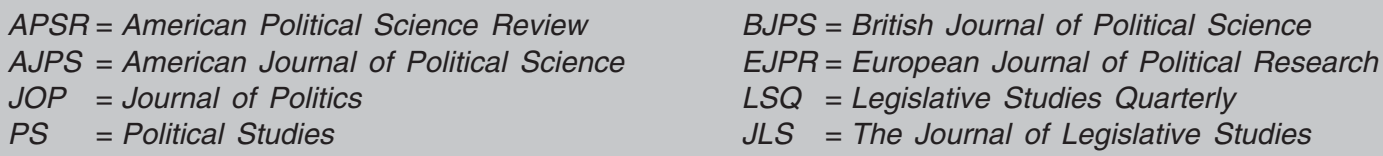

process of government formation. Finally, the category "other" accounts for $2 \%$ of articles, many of which deal with public perception of members and the institution. Exploring the specialist journals, both publish a significant proportion of research on organizational structures and committees, with the $L S Q$ publishing significantly more on voting patterns, candidates and incumbency, and electoral responsiveness than the JLS. The JLS in turn publishes significantly more on legislativeexecutive relations (more than twice as much as $L S Q$ ), bicameralism, and the role of national parliaments in what is now the European Union.

The above patterns notwithstanding, it is in terms of subject matter that legislative studies seems least divided. A great deal of eclecticism in legislative scholarship exists in both the United States and Europe, although some subjects are certainly more studied than others, overall and when I contrasted output from journals on different sides of the Atlantic. It is also worth noting that, for the three general European journals, the focus on coalition theory may overestimate the true level of legislative studies, given that, as mentioned in the section on demarcating legislative studies, some consider theories of government formation to be outside the realm of legislative studies.

\section{Authorship and Collaboration}

If most legislative scholarship is published in American journals and about American legislatures, one of the last hopes for a unified sub-discipline is the presence of cross-regional authorship and collaboration. Table 7 reports the distribution of authorship by country of institutional affiliation for each author of each article. ${ }^{6}$ As one might expect, it is mostly American scholars who publish legislative studies articles in American journals and mostly European scholars who publish legislative studies articles in European journals. The exception is the BJPS where over half of all legislative studies articles are published by American-based academics. This trend is also present, to a lesser degree, in the three other European journals. Overall, an American-based scholar is far more likely to publish a legislative studies article in a European journal than a European-based academic is likely to publish a legislative studies article in an American journal. This finding suggests that the data already presented in this paper overestimates the significance of legislative studies in Europe, given that a significant proportion of European legislative scholarship originates not in Europe but in the United States.

A key indicator of the internationalization of a discipline is the extent to which researchers from different countries work together. Correspondingly, the degree of non-collaborative research or intraregional research can be taken as a measure of the regionalization of a discipline. The most obvious indicator of collaboration is joint or multiple signings of research articles. ${ }^{7}$ While not all collaborative projects get to the publication stage, we can most easily measure cooperation patterns that result in journal articles.

Tables 8 and 9 report the coauthorship patterns for legislative studies articles based on the author's country of residence. The pattern is one of little interregional collaboration. Scholars within the same region conduct the vast bulk of research, either in single or intraregional collaboration. American collaborators co-authored 247 articles in the four U.S. journals (Table 8), while 32 articles were published in the four European journals by all-American teams (Table 9). In contrast, only the equivalent of four articles have been published by teams comprised of American and European scholars in 
Table 7

Distribution of Authorship by Country of Institutional Affiliation as a Percent of all Legislative Studies Articles

\begin{tabular}{lrrrrrrrr}
\hline & APSR & AJPS & JOP & \multicolumn{1}{c}{ LSQ } & \multicolumn{1}{c}{ PS } & BJPS & EJPR & JLS \\
\hline United States & 96.4 & 97.9 & 96.3 & 94.1 & 17.9 & 51.2 & 28.9 & 24.7 \\
Canada & 0.0 & 0.5 & 0.0 & 0.6 & 0.0 & 11.1 & 7.9 & 3.2 \\
South America & 0.0 & 0.3 & 0.0 & 0.5 & 0.0 & 0.0 & 0.0 & 1.7 \\
United Kingdom & 0.9 & 0.5 & 0.6 & 1.3 & 67.9 & 23.5 & 7.9 & 41.2 \\
$\quad$ and Ireland & & & & & & & & \\
Rest of Europe & 0.9 & 0.0 & 0.0 & 2.5 & 7.1 & 12.3 & 52.6 & 23.3 \\
Rest of World & 1.8 & 0.8 & 3.0 & 1.1 & 7.1 & 1.9 & 2.6 & 5.9 \\
Total & 100 & 100 & 100 & 100 & 100 & 100 & 100 & 100 \\
\hline
\end{tabular}

Note: Each unit represents a journal article. For example, for an article coauthored by an American, Canadian, and British, each country scores .33.

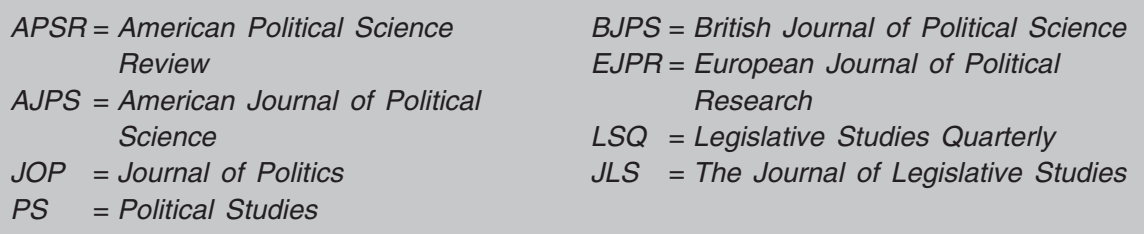

\section{Table 8}

Co-Authorship Patterns among Legislative Scholars in Four American Journals

\begin{tabular}{lcccccc}
\hline & $\begin{array}{c}\text { United } \\
\text { States }\end{array}$ & Canada & $\begin{array}{c}\text { South } \\
\text { America }\end{array}$ & $\begin{array}{c}\text { United } \\
\text { Kingdom/ } \\
\text { Ireland }\end{array}$ & $\begin{array}{c}\text { Rest of } \\
\text { Europe }\end{array}$ & $\begin{array}{c}\text { Rest of } \\
\text { World }\end{array}$ \\
\hline United States & 247 & 0 & 2 & 2 & 2 & 3 \\
Canada & - & 0 & 0 & 0 & 1 & 0 \\
South America & - & - & 0 & 0 & 0 & 0 \\
$\begin{array}{l}\text { United Kingdom/ } \\
\text { Ireland }\end{array}$ & - & - & - & 0 & 1 & 0 \\
Rest of Europe & - & - & - & - & 1 & 0 \\
Rest of World & - & - & - & - & - & 2 \\
\hline
\end{tabular}

Note: Each unit represents a journal article. For example, for an article coauthored by an American, Canadian and British, each country scores .33.

\section{Table 9 \\ Co-Authorship Patterns among Legislative Scholars in Four European Journals}

\begin{tabular}{|c|c|c|c|c|c|c|}
\hline & $\begin{array}{l}\text { United } \\
\text { States }\end{array}$ & Canada & $\begin{array}{c}\text { South } \\
\text { America }\end{array}$ & $\begin{array}{l}\text { United } \\
\text { Kingdom/ } \\
\text { Ireland }\end{array}$ & $\begin{array}{l}\text { Rest of } \\
\text { Europe }\end{array}$ & $\begin{array}{c}\text { Rest of } \\
\text { World }\end{array}$ \\
\hline United States & 32 & - & 1 & 4.33 & 6.33 & 2 \\
\hline Canada & - & - & 0 & 0 & 0 & 1 \\
\hline South America & - & - & 2 & 0 & 0 & 0 \\
\hline $\begin{array}{l}\text { United Kingdom/ } \\
\text { Ireland }\end{array}$ & - & - & 一 & 20 & 13.33 & 2 \\
\hline Rest of Europe & - & - & - & - & 15 & 0 \\
\hline Rest of World & - & - & - & - & - & 2 \\
\hline
\end{tabular}

Note: Each unit represents a journal article. For example, for an article coauthored by an American, Canadian and British, each country scores .33. the four American journals. In European journals, the rate of American-European collaboration is only slightly higher with the equivalent of 10 papers emerging from cross-Atlantic collaboration. Europeans are less likely to collaborate with each other than Americans with other Americans (reflecting the dominance of American authors), but are still more likely to collaborate with each other than with Americans. Overall, the lack of interregional collaboration and the presence of significantly more intraregional research teams provide further evidence of a division between legislative studies in the United States and Europe.

\section{Conclusion}

I used bibliometric data from eight of the leading journals in the discipline to shed light on the state of legislative studies as a sub-discipline. These data highlight the major differences between European and North American legislative scholarship. The analysis shows that a disproportionate amount of journal space is given to reporting research on the U.S. Congress, particularly the House of Representatives, while there is a dearth of reported research on other legislatures in my sample. General American journals publish a disproportionate share of all legislative scholarship compared with general European journals. The content analysis of articles points to the absence of a unified methodological approach to studying legislatures. With regard to the specific subject matter, U.S. scholars are more interested in electoral responsiveness while a significant proportion of legislative studies published in the sample of European journals focuses on executive-legislative relations. The pattern of authorship shows that Americanbased scholars contribute a significant proportion of legislative scholarship that is published in European journals while Europeans rarely publish legislative scholarship in American journals. The existence of the Atlantic divide is perhaps most evident when we consider the miniscule levels of interregional collaboration between scholars from the two continents-legislative scholars are far more likely to collaborate with scholars from the same side of the Atlantic. Overall then, the analysis of published articles identifies a clear divide between European and North American legislative scholarship.

This article has shed some light on the state and recent development of legislative studies in the United States and Europe. Is the observed divide a good or bad thing? It could be argued that multiple paradigms existing side by side are a 
breach of the Lakatosian notion of advancement in science and knowledge. If so, it is up to this generation of scholars to bridge the divide. A less negative view of the Atlantic divide would emphasize the contribution of different houses of research to methodological and substantive pluralism in legislative studies. Proponents of this view would surely be less than pleased at any attempt to unify legislative studies. A next step may be to attempt an understanding of the cause of the divide. This task, with all the political baggage of divided disciplines, may prove somewhat more difficult.

At a more practical level we can promote efforts to bridge the research gap

\section{Notes}

1. Bibliometrics is the application of measurements and indicators to books and other publications. For an introduction to and history of the field see Okubo (1997). An indication of the weakness of metric-based studies of the social sciences can be gleaned from browsing the table of contents of Scientometrics.

2. Laver and Schofield (1990) for example, comment on the growing divergence between what they call the European Politics tradition and the Game-Theoretic tradition in the study of multi-party government.

\section{References}

Bryce, James. 1921. Modern Democracies. London: Macmillan.

Budge, Ian. 1973. "Recent Legislative Research: Assumptions and Strategies." European Journal of Political Research 1 (4): 317-30.

Crewe, Ivor, and Pippa Norris. 1991. "British and American Journal Evaluation: Divergence and Convergence." PS: Political Science \& Politics 24 (September): 524-31.

Döring, Herbert, ed. 1995. Parliaments and Majority Rule in Western Europe. New York: St. Martin's Press.

Gamm, G., and J. Huber. 2002. "Legislatures as Political Institutions: Beyond the Contemporary Congress." In Political Science: The State of the Discipline III, ed. Ira Katznelson and Helen V. Milner. Washington, D.C.: American Political Science Association.

Garand, James C. 2005. "Integration and Fragmentation in Political Science: Exploring Patterns of Scholarly Communication in a Divided Discipline." Journal of Politics 67 (4): 979-1,005.

Garand, James C., and Micheal W. Giles. 2003. "Journals in the Discipline: A Report on a New Survey of American Political Scientists." PS: Political Science \& Politics 36 (April): 293-308.

Giannetti, Daniela, and Kenneth Benoit, eds. 2008. Intra-Party Politics and Coalition between European and American legislative studies. More European scholars are paying more attention to parliaments and more American scholars are engaging with legislatures outside their own jurisdictions. Unifying legislative studies requires making American and European scholars more interested in, and more willing to do research on, European legislative politics. It requires European scholars to build on, and perhaps reshape, the theoretical approaches to legislative scholarship in the United States. Professional groups such as the APSA Legislative Studies Section and the ECPR Standing Group on Parliaments

3. Garand and Giles (2003) rank $L S Q$ nineteenth of 124 journals among American political scientists.

4. This is evident, for example, in the fact that the American Political Science Association currently has 36 organized sections and the European Consortium for Political research currently has 32 Standing Groups.

5 . Just $3 \%$ of articles have no empirical focus whatsoever. could work together to provide avenues for scholars to communicate with each other and, potentially, collaborate. Indeed, the recent establishment of the ECPR Standing Group on Parliaments that aims to encourage the promotion of legislative scholarship on and within Europe is a significant development. Panels at the APSA Annual Meeting or the planned ECPR Annual Summer School on Parliaments could serve as a forum to bring together American and European scholars to discuss the differences outlined in this paper and think systematically about opportunities to integrate and unify the field of legislative studies.
Governments in Parliamentary Democracies. London: Routledge.

Green, Donald, and Ian Shapiro. 1994. Pathologies of Rational Choice Theory. New Haven, CT: Yale University Press.

King, Gary, Robert O. Keohane, and Sidney Verba. 1994. Designing Social Inquiry. Princeton, NJ: Princeton University Press. Laver, Michael, and Norman Schofield. 1990. Multiparty Government: The Politics of Coalition in Europe. New York: Oxford University Press.

Loewenberg, Gerhard, Samuel C. Patterson, and Malcolm E. Jewell, eds. 1985. Handbook of Legislative Research. Cambridge, MA: Harvard University Press.

Mezey, Michael L. 1991. "Studying Legislatures: Lessons for Comparing the Russian Experience." In Democratization in Russia: The Development of Legislative Institutions, ed. W. H. Jeffrey. New York: M.E. Sharpe. 1993 "Legislatures: Individual Purpose and Institutional Performance." In Political Science: The State of the Discipline II, ed. Ada W. Finifter. Washington, D.C.: American Political Science Association.

Monroe, Kristen Renwick, ed. 2005. Perestroika! The Raucous Revolution in Political Science. New Haven, CT.: Yale University Press.

Morris-Jones, W.H. 1983. "The Politics of Political Science: The Case of Comparative
6. For co-authors from different countries, each country scores a fraction, depending on the number of authors. Thus, if a publication is coauthored by a person from the United States and a person from the United Kingdom, then the number of authors from the U.S. increases by .5 , as does the number of authors from the UK.

7. Some collaborators may still choose to publish independently.
Legislative Studies.” Political Studies 31 (1): $1-24$.

Norris, Pippa. 1997. "Towards a More Cosmopolitan Political Science?" European Journal of Political Research 30 (1): 17-33.

Okubo, Yoshiko. 1997. "Bibliometric Indicators and Analysis of Research Systems: Methods and Examples." OECD Science, Technology and Industry Working Papers. Paris: OECD.

Pasquino, Gianfranco. 1973. "Elective Assemblies." European Journal of Political Research 1 (4): 331-56.

Patterson, Samuel C. 1989. "Understanding the British Parliament." Political Studies 37:449-62.

Shepsle, Kenneth A. 2002. "Assessing Comparative Legislative Research." In Legislatures: Comparative Perspectives on Representative Assemblies, ed. Gerhard Loewenberg, Peverill Squire, and D. Roderick Kiewiet. Ann Arbor: University of Michigan Press.

Shepsle, Kenneth A., and Barry R. Weingast, eds. 1995. Positive Theories of Congressional Institutions. Ann Arbor: University of Michigan Press.

Strøm, Kaare. 1997. "Rules, Reasons and Routines: Legislative Roles in Parliamentary Democracies." In Members of Parliament in Western Europe: Roles \& Behaviour, ed. Wolfgang C. Müller and Thomas Saalfeld. London: Frank Cass. 


\section{Appendix: Demarcating Legislative Studies}

Legislative institutions, typically referred to as legislatures, parliaments, congresses, or assemblies, are ubiquitous. ${ }^{1}$ Although scholars may argue about their role, structure, significance, and importance, it is almost impossible to study the politics of any country without reference to its legislature or legislatures. ${ }^{2}$ Within parliamentary systems, the legislature serves as the link between voters and the executive-within presidential systems the legislative branch acts as a balance against executive power. Consequently, the national parliament is a key political institution and is therefore frequently difficult, if not impossible, to divorce from other political institutions.

Take, for example, electoral systems and the study of elections. An electoral system provides the means to transform votes into seats. When discussing the election of legislators, it seems obvious to think of electoral systems as a legitimate area of interest to legislative scholars. Ballot structures not only determine the composition of the assembly, they may also shape the behavior and roles of members. Electoral-system research seems, however, to have developed as its own subdiscipline separate from legislative studies.

Another field of research that may or may not be considered part of legislative scholarship is the study of government formation and survival. Coalition theorists seek to explain, among other things, which governments emerge under parliamentarism when no single party controls a majority of seats in the legislature. Empirically and theoretically, the unit of analysis is often the legislative party. If in parliamentary systems the making and breaking of governments, through the vote of investiture and vote of confidence mechanisms, is a key power of parliament then should it not be considered part of legislative studies? Alternatively, a case could be made for considering coalition theory as part of the sub field of political science focused on political parties.

How then, should we demarcate legislative studies as a subfield? Is any aspect of politics that in some way involves the legislature the legitimate concern of legislative scholars? As a discipline develops its members specialize. This is clearly what has happened in political science with the emergence of many, often distinctive, subfields. ${ }^{3}$ Given the possible criticism that too many boundaries exist in the discipline it may not be very useful to clarify them, although it is clearly necessary if we want to talk about the state of legislative studies as a field of research. ${ }^{4}$

For the purpose of this study, legislative studies is defined as the behavioral and institutional study of parliamentary bodies and their interaction with other actors, taking account of the existence of other subfields in political science. For example, where research examined the interaction of parliamentary behavior and electoral systems (for example, the electoral responsiveness of members), we take this research to be legislative studies. We exclude electoral studies that focus, for example, on voter behavior more generally. Similarly, government formation is considered an area of legislative scholarship as is executive-legislative relations. It is worth emphasizing that I provide this definition with the aim of achieving some methodological preciseness for our study rather than as an attempt to establish a commonly acceptable boundary.

\section{Notes}

1. Notwithstanding important differences in origin and meaning, I have used the terms legislature, parliament, and assembly interchangeably throughout the paper.

2. The idea that parliaments are weak institutions is prevalent, particularly in the literatureon non-American legislatures and can be traced to the writings of Bryce on the decline of the British House of Commons (Bryce 1921). A glance at most country textbooks gives an indication of the centrality of the national parliament with at least one chapter being dedicated to the institution.

3. This is reflected, for example, in the fact that the American Political Science Association currently has 36 organized sections and the European Consortium for Political research currently has 32 Standing Groups.

4. One example is the failure of coalition theory to incorporate questions of interest to mainstream legislative scholars, such as the unitary actor assumption of legislative parties, although see Giannetti and Benoit (2008) for recent work in this area. 